\title{
Hajj Specific Appropriate Medication and Antibiotic Prescription: A Call for Development
}

\author{
Hamid Bokhary a, b, d Osamah Barasheed ${ }^{\text {c, d }}$ \\ aUmm Al-Qura University Medical Center, Umm Al-Qura University, Makkah, Saudi Arabia; ${ }^{b}$ Sydney School of Public \\ Health, The University of Sydney, Sydney, NSW, Australia; 'Executive administration for research and innovation, \\ King Abdullah Medical City, Makkah, Saudi Arabia; 'Basira Center for Health Research Training and Consulting, \\ Makkah, Saudi Arabia
}

Monitoring medication and antibiotic prescription has been in the World Health Organization (WHO)'s agenda since the end of the 20th century [1]. As monitoring such prescriptions would provide indicators for irresponsible use of drugs, follow-up on related policy effects, and quality control. However, most guidance on the matter requires updating, due to improvements in health services in most parts of the world since then, such as the availability of hospital information systems (HIS) for developing countries [2]. The WHO suggested some indicators for investigating drug use within health facilities, in 1993 [3]. Now, nearly 3 decades away, this guidance was not updated as there are still no indicators that utilize the potential reporting by HIS. Moreover, the WHO considers HIS an important building block for any health system and has devised a manual for monitoring them, which is more recent than the previously mentioned guidance [4]. As an appropriate practice in investigating drug use in health facilities, the WHO should include the ability of HIS to assess the utilization patterns of medication and commodities in their HIS assessment tool [4]. However, not all localities have installed HIS within their facilities, such with some countries in the middle east [5]. Therefore, further studies are required to update indicators for medication and antibiotic use, considering the specificities of local health profiles or contexts, such as Hajj.

Hajj is a large mass gathering event that takes place in Makkah, Saudi Arabia, every year. Excluding the recent coronavirus disease 2019 pandemic, more than 2 million pilgrims attend this event from more than 180 countries [6]. Traveling from both hemispheres and overcrowding during Hajj rituals may expose pilgrims to several health risks [7]. These health risks can be categorized by their origin into environmental, human, and emergent [7-12]. Most of them can be avoided and mitigated by careful planning, thorough governance, and appropriate practices [13-15]. Irrefutably, the Saudi government has covered the planning and governance part of risk management, and they are constantly updating their approaches. However, the challenges in Hajj are with health service providers to improve their methods and invest in appropriate practices.

There were reports from medical practitioners of crowding on their clinics during Hajj, which may overstress the locally deployed health services for the event [16]. Such high number of medical complaints would require similarly substantial volume of dispensed medication, which the health authorities provide for free during
C 2021 The Author(s).

Published by S. Karger AG, Basel

This is an Open Access article licensed under the Creative Commons Attribution-NonCommercial-4.0 International License (CC BY-NC) (http://www.karger.com/Services/OpenAccessLicense), applicable to the online version of the article only. Usage and distribution for commercial purposes requires written permission.
Correspondence to:

Hamid Bokhary, hamid.bokhary@ sydney.edu.au 
the event [17]. A recent study found that the average number of medications prescribed per hospital outpatient's visit during Hajj is 2.6 [18], which is over the reference value that has been used to compare, 1.6-1.8 medication per encounter [19]. Additionally, reports of pilgrims receiving antibiotic prescription during Hajj ranged $47-95 \%[18,20,21]$, higher than the same reference values used above, $20-26.8 \%$ of encounters [19]. However, unnecessary and overuse of antibiotics accelerates the timeline for organisms to develop antimicrobial resistance (AMR) [22]. The aforementioned studies were conducted on hospital outpatient clinics during Hajj $[18,20]$. However, this setting reflects $13 \%$ of pilgrims receiving health services from the Ministry of Health during Hajj [23]. While the majority of pilgrims (79\%) visit primary health-care settings in Hajj [23]. Hence, further studies are required, including primary care settings, to complete the picture of medication and antibiotic utilization in Hajj, and to assist in guiding health-care workers with evidence-based appropriate prescription practices.

Although Hajj is a unique mass gathering with multiple variables that expresses diversity in each season; however, it is a potential focal point for dissemination of infectious organisms and AMR globally [24-27]. Although respiratory complaints are common in Hajj; however, patterns of AMR bacteria associated with upper respiratory tract infections (URTIs) require further investigation [28]. Whereas regarding infectious diseases, Hajjspecific guidance and supporting decision tools, which do not hinder the normal flow of the event, are still yet to be developed. Hence, to our knowledge, there are still no guidelines or scoring systems for prescribing antibiotics for URTIs that are developed for Hajj context. Therefore, we conducted a trial during Hajj 2018 to assess the rate of appropriate prescriptions for URTIs in Hajj (not published). Based on the results, we will attempt to develop a tool to help health-care workers in their practices for prescribing antibiotics for URTIs in Hajj.
This is a call for fellow Hajj researchers to develop indicators, reference values, guidance, and assessment tools for prescribing medications and antibiotic utilization during the event. Challenges for such studies include low synergy levels between different service authorities, near absence for expenditure on research, and recent research focus shift from communicable to noncommunicable diseases during Hajj [29-31]. Fortunately, recent reforms have provided basis for mitigating such obstacles, that is, the Saudi 2030 Vision. The vision enforces several reforms, which include 3 main aspects that can help Hajj researchers: strong roots in serving pilgrims, fulfilling lives through health, and effective governance through transparency and engagement [32]. From field experience: this has yet to settle to cover research studies that are not bound by institutional privileges. Moreover, the field of Hajj research is dynamic, and each season may have different and unique research opportunities due to the constant shift of interests. Conclusively, a researcher must be vigilant, present, and attentive to the interferences that may arise while conducting Hajj research, such skills and attributes are further tuned with each season experienced.

\section{Conflict of Interest Statement}

The authors have no conflicts of interest to declare.

\section{Funding Sources}

No funding was obtained or sought for this commentary.

\section{Author Contributions}

Hamid Bokhary: conceptualization, writing - original draft, and writing - review and editing; and Osamah Barasheed: conceptualization and writing - review and editing.

\section{References}

1 World Health Organization. Introduction to Drug Utilization Research. Geneva, Switzerland: WHO; 2003. Available from: https://apps. who.int/iris/rest/bitstreams/50537/retrieve.

2 Moghaddasi H, Mohammadpour A, Bouraghi H, Azizi A, Mazaherilaghab H. Hospital information systems: the status and approaches in selected countries of the Middle East. Electron Physician. 2018;10(5):6829-35.

3 World Health Organization. How to investigate drug use in health facilities: selected drug use indicators. Geneva, Switzerland: WHO; 1993. Available from: https://apps.who.int/ iris/bitstream/handle/10665/60519/WHO_ DAP_93.1.pdf.

4 World Health Organization. Monitoring the building blocks of health systems: a handbook of indicators and their measurement strategies. Geneva, Switzerland: WHO; 2010. Available from: https://www.who.int/healthinfo/systems/WHO_MBHSS_2010_full_ web.pdf. 
5 Alsadan M, El Metwally A, Ali A, Jamal A, Khalifa M, Househ M. Health information technology (HIT) in Arab countries: a systematic review study on HIT progress. J Health Inform Dev Ctries. 2015;9(2). https:// www.jhidc.org/index.php/jhidc/article/ view/138.

6 Ebrahim SH, Memish ZA. Saudi Arabia's drastic measures to curb the COVID-19 outbreak: temporary suspension of the Umrah pilgrimage. J Travel Med. 2020;27(3):taaa029.

7 Ahmed QA, Arabi YM, Memish ZA. Health risks at the Hajj. Lancet. 2006;367(9515): 1008-15.

8 Simpson IJ, Aburizaiza OS, Siddique A, Barletta B, Blake NJ, Gartner A, et al. Air quality in Mecca and surrounding holy places in Saudi Arabia during Hajj: initial survey. Environ Sci Technol. 2014;48(15):8529-37.

9 Seraj MA, Channa AB, Sharif AY, Kadiwal $\mathrm{GH}$, Jamjoom A. Heat related illnesses during the Hajj (pilgrimage)-emerging role of the anesthesiologist. Middle East J Anaesthesiol. 1987;9(3):255-76.

10 Fouz N, Pangesti KNA, Yasir M, Al-Malki AL, Azhar EI, Hill-Cawthorne GA, et al. The contribution of wastewater to the transmission of antimicrobial resistance in the environment: implications of mass gathering settings. Trop Med Infect Dis. 2020;5(1):33.

11 Khan AA, Noji EK. Hajj stampede disaster, 2015: reflections from the frontlines. Am J Disaster Med. 2016;11(1):59-68.

12 Hoang VT, Gautret P, Memish ZA, Al-Tawfiq JA. Hajj and Umrah mass gatherings and COVID-19 infection. Curr Trop Med Rep. 2020: $1-8$.

13 Jokhdar H, Khan A, Asiri S, Motair W, Assiri A, Alabdulaali M. COVID-19 mitigation plans during Hajj 2020: a success story of zero cases: Health security; 2020.

14 Alaska YA, Aldawas AD, Aljerian NA, Memish ZA, Suner S. The impact of crowd control measures on the occurrence of stampedes during mass gatherings: the Haji experience. Travel Med Infect Dis. 2017;15:67-70.
15 Elachola H, Assiri AM, Memish ZA. Sun protection during the Hajj mass-gathering-2013. Travel Med Infect Dis. 2014;12(6 Pt B):783-4.

16 Bokhary H, Barasheed O, Abd El Ghany M, Khatami A, Hill-Cawthorne GA, Rashid $\mathrm{H}$. Pilot survey of knowledge, attitudes and perceptions of Hajj deployed health care workers on antibiotics and antibiotic prescriptions for upper respiratory tract infections: results from two Hajj seasons. Trop Med Infect Dis. 2020;5(1):18.

17 Shafi S, Dar O, Khan M, Khan M, Azhar EI, McCloskey B, et al. The annual Hajj pilgrimage-minimizing the risk of ill health in pilgrims from Europe and opportunity for driving the best prevention and health promotion guidelines. Int J Infect Dis. 2016;47:79-82.

18 Yezli S, Zaraa S, Yassin Y, Mushi A, Stergachis A, Khan A. Medication utilization pattern among outpatients during the Hajj mass gathering. Saudi Pharm J. 2020;28(9):1122-8.

19 Isah A, Laing R, Quick J, Mabadeje A, Santoso $\mathrm{B}$, Hogerzeil $\mathrm{H}$, et al. The development of reference values for the WHO health facility core prescribing indicators. WAJPDR. 2001;18:611.

20 Alherabi AZ. Road map of an ear, nose, and throat clinic during the 2008 Hajj in Makkah, Saudi Arabia. Saudi Med J. 2009;30(12):15849.

21 Hoang VT, Nguyen TT, Belhouchat K, Meftah M, Sow D, Benkouiten S, et al. Antibiotic use for respiratory infections among Hajj pilgrims: a cohort survey and review of the literature. Travel Med Infect Dis. 2019;30:3945.

22 O’Neill J. Tackling drug-resistant infections globally: final report and recommendations. Review on Antimicrobial Resistance; 2016. Available from: https://amr-review.org/sites/ default/files/160525_Final\%20paper with\%20cover.pdf.

23 Saudi Ministry of Health. Ministry of health annual report, 1439/1440H; 2018. Available from: https: //www.moh.gov.sa/Ministry/ About/Documents/MOH-Report-2018.pdf.
24 Hagmann SHF, Angelo KM, Huits R, Plewes K, Eperon G, Grobusch MP, et al. Epidemiological and clinical characteristics of International travelers with enteric fever and antibiotic resistance profiles of their isolates: a geosentinel analysis. Antimicrob Agents Chemother. 2020;64(11):e01084-20.

25 Abd El Ghany M, Alsomali M, Almasri M, Padron Regalado E, Naeem R, Tukestani A, et al. Enteric infections circulating during Hajj seasons, 2011-2013. Emerg Infect Dis. 2017; 23(10):1640-9.

26 Hoang VT, Dao TL, Ly TDA, Sow D, Belhouchat K, Larbi Chaht K, et al. Gastrointestinal symptoms and the acquisition of enteric pathogens in Hajj pilgrims: a 3-year prospective cohort study. Eur J Clin Microbiol Infect Dis. 2020.

27 Bokhary H, Rashid H, Hill-Cawthorne GA Abd El Ghany M. The rise of antimicrobial resistance in mass gatherings. In: Laher I, editor. Handbook of healthcare in the Arab world. Cham: Springer International Publishing; 2020. p. 1-16. Available from:

28 Marglani OA, Alherabi AZ, Herzallah IR, Saati FA, Tantawy EA, Alandejani TA, et al. Acute rhinosinusitis during Hajj season 2014: prevalence of bacterial infection and patterns of antimicrobial susceptibility. Travel Med Infect Dis. 2016;14(6):583-7.

29 Yezli S, Khan A, Bouchama A. Summer Hajj pilgrimage in the era of global warming: a call for vigilance and better understanding of the risks. J Travel Med. 2019;26(7):taz069.

30 Sardar Z. The information unit of the Hajj research centre. Aslib Proc. 1978;30(5):158-64.

31 D'Alessandro K, Leggio WJ Jr, Al Mubaireek $\mathrm{H}$. World's largest gathering: muslim mass pilgrimage poses EMS logistical \& planning challenges. J Emerg Med Ser. 2013;38(9):527.

32 Government of Saudi Arabia. Saudi vision 2030: an ambitious vision for an ambitious nation; 2016. Available from: https://www.vision2030.gov.sa/media/rc0b5oy1/saudi_vision203.pdf. 